\title{
Have Acquisitions of Failed Banks Increased the Concentration of U.S. Banking Markets?
}

\author{
David C. Wheelock
}

\begin{abstract}
During 2007-10, failures eliminated 318 U.S. commercial banks and savings institutions, about 4 percent of the total number of banks operating at the end of 2006. The assets and deposits of many failed banks were acquired by institutions that already had offices in markets served by the failed banks. This article investigates the impact of in-market acquisitions of failed banks on the concentration of local U.S. banking markets. Most banks that failed during 2007-10 were small, and their acquisitions generally had little impact on market concentration. Acquisitions of larger banks that failed, such as the acquisition of Washington Mutual Bank by JPMorgan Chase Bank, also had only limited impact on the concentration of most banking markets. Among large metropolitan statistical area markets, the Houston and New York City banking markets were most affected by the acquisition of Washington Mutual, but these markets remained relatively unconcentrated after the acquisition. Hence, the article finds that except for a few rural banking markets, acquisitions of failed banks by in-market competitors generally had only a small impact on market concentration. (JEL G21, G28, G34, L11, L41)
\end{abstract}

Federal Reserve Bank of St. Louis Review, May/June 2011, 93(3), pp. 155-68.

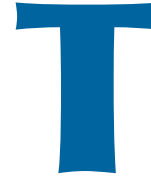

he financial crisis and recession of 2007-09 brought a sharp increase in the number of depository institution failures in the United States and elsewhere.

Between January 1, 2007, and December 31, 2010, a total of 318 U.S. commercial banks and savings institutions (hereafter "banks") failed-nearly 4 percent of the total number in operation on December 31, 2006. Failed banks held approximately $\$ 436$ billion of deposits-nearly 6 percent of the total deposits held in U.S. banks on December 31, 2006. ${ }^{1}$

Compared with firms in most other industries, banks are heavily regulated and supervised by government authorities. Furthermore, their principal form of liabilities-customer deposits-are insured by a government agency, the Federal Deposit Insurance Corporation (FDIC). Govern- ment authorities regularly examine all banks, especially those that have sustained substantial losses or show other signs of weakness that might lead to failure. Insolvent banks, or banks that appear in imminent danger of becoming insolvent, may be declared failed by their primary regulator in conjunction with the FDIC. The FDIC acts as the receiver or liquidating agent for federally insured banks that fail and is required by law to resolve each failure in the manner that imposes the least cost on the deposit insurance system.

\footnotetext{
1 Data on failed bank and savings institution deposits are from their last available quarterly statement of condition before failure. The data reported here are for failures of U.S. chartered commercial banks and savings institutions located in the 50 states and Washington, D.C., and exclude data for Puerto Rico and other U.S. territories, as well as for one bankers' bank, one cooperative bank, and two industrial banks that failed during the period and appear in the list of bank failures on the FDIC website (www.fdic.gov/bank/individual/failed/banklist.html).
} 
In recent years, most bank failures have been resolved through a "purchase and assumption" (P\&A) transaction in which some or all of the assets of the failed bank are sold to a healthy bank, which may also assume some or all of the failed bank's liabilities, including all insured deposits. ${ }^{2}$ The FDIC solicits bids from potential acquirers and is required by law to select the qualifying bid that imposes the least cost on the deposit insurance fund. (The FDIC usually pays the acquirer an amount based on the excess of the value of liabilities it assumes over the value of the assets or enters into a loss-sharing agreement with the acquiring bank.) Occasionally, however, failed banks are liquidated, with the FDIC paying off insured depositors and liquidating all of the failed bank's assets. Among the 318 failures noted above, 299 were resolved through P\&A transactions and 19 were resolved through a deposit payoff and liquidation or other means. ${ }^{3}$

This article examines how acquisitions of failed banks during 2007-10 affected the concentration of local U.S. banking markets. Concentration measures are used often to gauge the competitiveness of markets. Although the threat of entry by potential competitors may deter firms from exerting market power in industries with a small number of firms-even just one firm-a high degree of concentration is often taken as a sign of a lack of competition in a market. ${ }^{4}$ Further, researchers have found that banks in more concentrated local markets tend to charge higher interest rates on loans and pay lower rates on

2 Often, however, acquirers do not purchase the brokered deposits, whether insured or not, of failed banks.

3 A few of the 19 bank failures not resolved through standard P\&As were temporarily transferred to bridge banks, which are new, temporary national banks controlled by the FDIC. The FDIC uses bridge banks to provide the time needed to arrange a permanent transaction to resolve a failed bank. The FDIC considers bridge banks a form of P\&A transactions. However, this article focuses on the impact of acquisitions of failed banks by in-market competitors and, hence, does not consider the implications of bridge bank resolutions. Additional information about the resolution of failed banks can be found in the FDIC Resolutions Handbook (www.fdic.gov/bank/historical/reshandbook/).

4 If markets are "contestable" (i.e., if barriers to entry and exit are sufficiently low), then even a monopolist is unable to earn excess profits in the long run because other firms will enter and drive down the market price if the incumbent firm sets its price above marginal cost (Baumol, Panzar, and Willig, 1988). deposits. They also tend to behave more conservatively and be less cost efficient than banks in less concentrated markets. ${ }^{5}$ Bank regulators use Department of Justice guidelines for market concentration to evaluate the competitive effects of proposed bank mergers and acquisitions. Proposed transactions that would increase market concentration significantly are subject to more scrutiny and are more likely to be rejected on antitrust grounds than transactions that would not increase concentration significantly. ${ }^{6}$ In compiling lists of potential bidders for failed banks, the FDIC considers market competition, as well as other factors. However, the FDIC does not automatically reject bids that would increase market concentration significantly.

Bank regulators use data on deposits held at bank branch offices to measure the concentration of local banking markets. Similarly, this article uses these data to examine how acquisitions of failed banks have affected the concentration of local U.S. banking markets. The merger of two banks with no geographic markets in common will have no effect on the concentration of any local banking markets. However, acquirers of many failed banks have branches in markets served by the failed bank. This article investigates how such transactions have affected the concentration of local banking markets by comparing the actual levels of concentration in those markets before a bank failure with hypothetical, or "pro forma," levels constructed by treating the acquiring and failed banks as having merged before the date of failure. Further, for markets with many bank failures or especially large increases in concentration, the article evaluates how all failed bank acquisitions by in-market competitors since 2007 affected concentration. Although acquisitions of failed banks by in-market competitors produced large increases in concentration in a few, mainly rural, banking markets, such acqui-

\footnotetext{
5 Gilbert (1984) provides a comprehensive review of research on bank market structure and competition through the early 1980s, and Berger et al. (2004) review more recent research on the relationships between market concentration, competition, and bank performance.

6 See Gilbert and Zaretsky (2003) for more on the use of concentration in the competitive analysis of proposed bank mergers and acquisitions.
} 
sitions did not substantially affect concentration in most U.S. banking markets.

The next section reports summary information about banks that failed during 2007-10 and the institutions that acquired them. Subsequently, the article investigates the impact of acquisitions of failed banks by in-market competitors on the concentration of local banking markets. The article identifies markets where such acquisitions resulted in large increases in concentration, as well as the effect of in-market acquisitions of failed banks on concentration in markets that had many failures or especially large increases in concentration. The final section presents conclusions.

\section{ACQUIRERS OF FAILED BANKS}

The majority (94 percent) of the 318 failures of U.S. banks between January 1, 2007, and December 31, 2010, were resolved by P\&A transactions. In total, 178 banks acquired some or all of the assets and liabilities of one or more failed banks during this period. In general, the acquirers of failed banks were larger, in terms of both total assets and deposits, and operated more branch offices in more banking markets than failed banks. Table 1 lists the 10 largest failed banks and 10 largest acquirers of failed banks during 2007-10, based on total assets on June 30, 2006. Washington Mutual Bank, a federally chartered savings bank with $\$ 350.9$ billion of assets on June 30, 2006, was the largest bank that failed during the period. Its acquirer, JPMorgan Chase Bank, had \$1.1 trillion of assets on June 30, 2006, and was the largest acquirer of one or more failed banks during the 2007-10 period.

Table 2 reports summary information, as of June 30, 2006, for all failed banks and their acquirers. ${ }^{7}$ Information for failed commercial banks and savings institutions is reported separately.

\footnotetext{
7 The first bank failure during 2007-10 occurred in February 2007 and, hence, I use data from June 30, 2006, in compiling the summary information presented in Table 2. Although there were 318 failed banks during the period, nine of those banks were chartered after June 30,2006 , and thus the summary information in Table 2 is based on data for only 258 failed commercial banks and 51 failed savings institutions. Likewise, 12 of the 178 acquirers were chartered after June 30, 2006, and hence the summary information for acquirers is based on only 166 observations.
}

Savings institutions traditionally have focused on residential mortgage lending, and many experienced large losses when mortgage delinquencies rose during 2007-10. Several large savings institutions, including Washington Mutual Bank, failed during this period. Although many commercial banks also succumbed to the downturn in real estate markets, failed commercial banks tended to be smaller than failed savings institutions. The average (median) total assets and deposits of failed savings institutions were $\$ 9.5$ billion ( $\$ 352$ million) and $\$ 5.6$ billion ( $\$ 307$ million), respectively, whereas the comparable figures for failed commercial banks were $\$ 628$ million (\$223 million) and $\$ 478$ million (\$185 million).

Acquirers of failed institutions, which included both commercial banks and savings institutions, often were much larger than the firms they acquired. The average (median) total assets and deposits of acquiring institutions were $\$ 14.7$ billion ( $\$ 649$ million) and $\$ 7.8$ billion ( $\$ 466$ million), respectively. Acquirers also tended to operate more branch offices in more geographic areas than acquired banks. The largest acquirer (in terms of number of branches) operated 2,679 branches in 17 states and another operated branches in 26 states. The median number of branches operated by acquirers was 11 branches. Although the largest failed banks also had many branch offices, the median number of branches operated by failed commercial banks and savings institutions were 3 and 7, respectively, and most failed institutions operated branches in fewer unique zip code regions, counties, and states than did acquirers of failed banks. ${ }^{8}$

\section{IMPACT OF FAILED BANK ACQUISITIONS ON MARKET CONCENTRATION}

When it compiles a list of potential acquirers for a failed bank, the FDIC "takes into account the failed institution's geographic location, competitive environment, minority-owned status,

8 See Aubuchon and Wheelock (2010) for more information about the characteristics of banks that failed during 2007-10. 


\section{Table 1}

Ten Largest Failed Banks and Acquiring Institutions (January 2007-December 2010), by Total Assets on June 30, 2006

\begin{tabular}{|c|c|c|c|c|c|c|}
\hline Name of institution & $\begin{array}{l}\text { Total assets } \\
\text { (\$ thousands) }\end{array}$ & $\begin{array}{l}\text { Total deposits } \\
\text { (\$ thousands) }\end{array}$ & Total branches & $\begin{array}{l}\text { Total zip codes } \\
\text { with a branch }\end{array}$ & $\begin{array}{l}\text { Total counties } \\
\text { with a branch }\end{array}$ & $\begin{array}{c}\text { Total states } \\
\text { with a branch }\end{array}$ \\
\hline \multicolumn{7}{|l|}{ Failed banks } \\
\hline Washington Mutual Bank, FSB & $350,890,182$ & $210,626,236$ & 2,167 & 1,745 & 199 & 15 \\
\hline Colonial Bank, NA & $22,962,845$ & $16,242,689$ & 301 & 267 & 74 & 5 \\
\hline IndyMac Bank, FSB & $22,743,262$ & $9,575,579$ & 26 & 25 & 4 & 1 \\
\hline Downey Savings and Loan Association & $17,464,594$ & $11,936,431$ & 172 & 154 & 20 & 2 \\
\hline Guaranty Bank & $16,920,624$ & $9,362,598$ & 152 & 149 & 49 & 2 \\
\hline Ohio Savings Bank, FSB* & $16,605,531$ & $11,188,582$ & 56 & 52 & 8 & 3 \\
\hline BankUnited, FSB & $12,866,372$ & $6,014,740$ & 73 & 62 & 11 & 1 \\
\hline First Federal Bank of California, FSB & $10,256,842$ & $5,542,113$ & 32 & 28 & 2 & 1 \\
\hline Corus Bank, NA & $9,369,988$ & $8,320,397$ & 14 & 10 & 1 & 1 \\
\hline United Commercial Bank & $8,280,022$ & $5,497,301$ & 47 & 36 & 14 & 4 \\
\hline \multicolumn{7}{|l|}{ Acquiring institutions } \\
\hline JPMorgan Chase Bank, NA & $1,144,680,000$ & $434,752,000$ & 2,679 & 1,783 & 283 & 17 \\
\hline U.S. Bank, NA & $212,553,949$ & $117,337,830$ & 2,525 & 1,873 & 553 & 26 \\
\hline SunTrust Bank & $181,442,168$ & $117,956,301$ & 1,758 & 1,130 & 249 & 12 \\
\hline PNC Bank, NA & $85,946,560$ & $58,134,805$ & 831 & 588 & 77 & 9 \\
\hline Branch Banking and Trust Company & $85,214,955$ & $51,246,133$ & 918 & 718 & 239 & 10 \\
\hline Regions Bank & $81,954,710$ & $57,231,022$ & 1,397 & 1,039 & 398 & 15 \\
\hline ING Bank, FSB & $60,922,260$ & $46,440,495$ & 1 & 1 & 1 & 1 \\
\hline Manufacturers and Traders Trust Company & $55,789,617$ & $35,227,118$ & 683 & 492 & 101 & 7 \\
\hline Union Bank, NA & $50,054,634$ & $39,743,303$ & 340 & 296 & 40 & 3 \\
\hline Fifth Third Bank & $48,259,297$ & $38,388,498$ & 749 & 547 & 133 & 6 \\
\hline
\end{tabular}

NOTE: *On the date of its failure, Ohio Savings Bank was known as AmTrust Bank.

SOURCE: FDIC, Summary of Deposits. 


\section{Table 2 \\ Descriptive Statistics for Failed Banks and Acquiring Institutions (January 2007-December 2010)}

\begin{tabular}{|c|c|c|c|c|c|c|}
\hline Type of bank & $\begin{array}{l}\text { Total assets } \\
\text { (\$ thousands) }\end{array}$ & $\begin{array}{l}\text { Total deposits } \\
\text { (\$ thousands) }\end{array}$ & Total branches & $\begin{array}{l}\text { Total zip codes } \\
\text { with a branch }\end{array}$ & $\begin{array}{l}\text { Total counties } \\
\text { with a branch }\end{array}$ & $\begin{array}{r}\begin{array}{r}\text { Total sta } \\
\text { with a br }\end{array} \\
\end{array}$ \\
\hline \multicolumn{7}{|c|}{ Failed commercial banks (258 banks) } \\
\hline Min & 11,073 & 3,264 & 1 & 1 & 1 & 1 \\
\hline Max & $22,962,845$ & $16,242,689$ & 301 & 267 & 74 & 5 \\
\hline Mean & 628,081 & 478,117 & 7.1 & 6.2 & 2.7 & 1.1 \\
\hline Q1 & 94,722 & 74,991 & 1 & 1 & 1 & 1 \\
\hline Median & 223,099 & 185,124 & 3 & 3 & 2 & 1 \\
\hline Q3 & 490,770 & 380,402 & 7 & 6 & 3 & 1 \\
\hline SD & $1,769,355$ & $1,288,289$ & 20.5 & 18.0 & 5.1 & 0.5 \\
\hline \multicolumn{7}{|c|}{ Failed savings institutions (51 banks) } \\
\hline Min & 5,927 & 3,264 & 1 & 1 & 1 & 1 \\
\hline Max & $350,890,182$ & $210,626,236$ & 2,167 & 1,745 & 199 & 15 \\
\hline Mean & $9,494,080$ & $5,648,601$ & 60.3 & 50.4 & 9.1 & 1.7 \\
\hline Q1 & 112,088 & 84,525 & 1 & 1 & 1 & 1 \\
\hline Median & 351,608 & 307,481 & 7 & 7 & 2 & 1 \\
\hline Q3 & $1,765,954$ & $1,327,204$ & 20 & 15 & 5 & 2 \\
\hline SD & $49,046,846$ & $29,423,941$ & 302.8 & 244.0 & 28.5 & 2.1 \\
\hline \multicolumn{7}{|c|}{ Acquiring institutions (166 banks) } \\
\hline Min & 14,709 & 7,916 & 1 & 1 & 1 & 1 \\
\hline Max & $1,144,680,000$ & $434,752,000$ & 2,679 & 1,873 & 553 & 26 \\
\hline Mean & $14,693,641$ & $7,840,964$ & 106.3 & 77.8 & 20.9 & 2.0 \\
\hline Q1 & 224,488 & 160,555 & 4 & 4 & 2 & 1 \\
\hline Median & 648,627 & 465,562 & 11 & 9 & 4 & 1 \\
\hline Q3 & $2,664,282$ & $2,345,542$ & 43 & 33 & 12 & 2 \\
\hline SD & $91,894,739$ & $36,986,975$ & 353.1 & 248.8 & 64.0 & 3.0 \\
\hline
\end{tabular}

NOTE: Data are for June 30, 2006; Q1 and Q3 are values for the first and third quartiles of the distribution of the data; and SD is the standard deviation of the data. SOURCE: FDIC, Summary of Deposits. 
overall financial condition, asset size, capital level, and regulatory ratings" (FDIC, Resolutions Handbook, p. 9). A bank with significant operations in the markets served by a failed bank might be willing to bid more than other banks for the assets of the failed bank for several reasons. For example, an in-market bidder might have more information about the local market and the failed bank's customers, and thereby be able to serve those customers at lower cost than other potential bidders. The cost of absorbing the operations of the failed bank might also be lower for a local bidder. Further, a local bank might purchase a failed competitor to deter entry by outside competitors.

Many failed bank resolutions during 2007-10 involved the acquisition of some or all of the assets and deposits of the failed bank by an inmarket competitor (i.e., another bank that already operated at least one branch in markets served by the failed bank). Only 2 of 7 failures between January 1, 2007, and June 30, 2008, were resolved by a P\&A transaction in which an in-market competitor acquired the failed bank. However, 43 of 65 failures between July 1, 2008, and June 30, 2009; 84 of 175 failures between July 1, 2009, and June 30, 2010; and 42 of 71 failures between July 1, 2010, and December 31, 2010, were resolved by a P\&A in which an in-market competitor acquired the failed bank. Thus, a majority of failed bank resolutions during 2007-10 resulted in some consolidation of banking assets and deposits in local banking markets. ${ }^{9}$

Measures of market concentration, such as $n$-firm concentration ratios and the HerfindahlHirschman Index (HHI), are used often to help evaluate the competitiveness of banking and other markets. Banks are required to report the amount of deposits held by each of their branch offices on June 30 of each year. ${ }^{10}$ To enforce antitrust laws, bank regulators use these data to consider how

9 This article uses the common definition of banking markets as either metropolitan statistical areas (MSAs) or non-MSA counties. However, some U.S. banking markets are defined by regulators to encompass larger or smaller areas, and market definitions are sometimes changed to reflect changes in commuting patterns, population growth, and so on. Current definitions for all U.S. banking markets are available from the Federal Reserve Bank of St. Louis (http://cassidi.stlouisfed.org/). proposed bank mergers would affect the concentration of bank deposits in local banking markets. Ordinarily, proposed mergers are not challenged on competitive grounds unless they would result in a post-merger HHI value of more than 1800 points and an increase in the index of more than 200 points. ${ }^{11}$ These guidelines are not binding on the resolution of failed banks, but as noted previously, the FDIC does consider the competitiveness of banking markets when compiling lists of potential bidders for failed banks.

Similar to the approach used by bank regulators in antitrust enforcement, I estimate the impact of failed bank acquisitions on the concentration of local banking markets by comparing the actual values for each market in which both banks had branches with the pro forma HHI values calculated under the assumption that the acquiring and failed banks had merged before the bank failure. Obviously, the merger of two banks that share no geographic markets will have no impact on the HHI values of any local banking markets. However, the merger of banks that operate in the same markets will, all else equal, reduce the number of banks in those markets and increase the deposits held by the acquiring bank, and thereby increase the value of the HHI.

Estimates of market concentration, such as the HHI, require data on the allocation of customer deposits across bank branches. For banking markets (metropolitan statistical areas [MSAs] or county) in which an acquisition of a failed bank occurred, I use these data to calculate HHI values for the June 30 immediately preceding a bank's failure. For example, I use branch-level deposits data from June 30,2007 , to calculate HHI values for all markets in which one or more banks that failed between July 1, 2007, and June 30, 2008, were acquired by in-market competitors. I then compare actual HHI values for June 30, 2007, with

\footnotetext{
${ }^{10}$ These data are available from the FDIC

(http://www2.fdic.gov/sod/index.asp).

11 The HHI is calculated as the sum of the squared market shares of each firm competing in a market-that is, $H H I=\Sigma_{i}$ market share $_{i}^{2}$, where there are $i=1, \ldots, n$ firms in the market and market share ${ }_{i}$ is the percentage of market output (deposits in the present context) produced by the $i$ th firm. Guidelines for the use of the HHI in antitrust enforcement are established by the Department of Justice (www.justice.gov/atr/public/guidelines/6472.htm).
} 
pro forma values calculated under the assumption that the failed and acquiring banks had already been operating as a single institution on that date. ${ }^{12}$

Most acquisitions of failed banks by in-market competitors during 2007-10 did not result in a substantial increase in local market concentration. Comparing actual HHI values on the June 30 before a bank failure with pro forma values derived by assuming that the failed bank and its acquirer had already merged, I find that acquisitions of failed banks by in-market competitors resulted in an average increase in HHI value of 54.1 points and a median increase of just 1.3 points. Further, I estimate that the acquisition of a failed bank by an in-market competitor increased the HHI value by more than 200 points in only 21 markets, which are listed in Table 3. As shown in the table, the 15 markets with the largest difference between the pro forma HHI and pre-failure HHI values (i.e., difference between "Pro Forma HHI" and "HHI Before Acquisition") are all sparsely populated non-MSA counties. Transactions resulting in a difference greater than 200 points also occurred in six MSAs, five of which are relatively small. ${ }^{13}$

Whereas Table 3 lists markets where the differences between the hypothetical and pre-failure HHI values exceed 200 points, Table 4 lists markets where the pre-failure HHI exceeded 1800 points, which is the level at which the Department of Justice considers a market to be concentrated. Terrell County, Texas, was the most concentrated U.S. banking market in which a failed bank was acquired by another in-market bank. Sanderson

\footnotetext{
${ }^{12}$ Regulators weight the deposits of savings institutions by 0.5 when calculating HHI values for use in competitive analysis of local banking markets, reflecting a presumption that deposits at savings institutions are similar, but not perfect, substitutes for deposits at commercial banks. For this article, however, I assign full weight to savings institutions' deposits when calculating HHI values. Since the article focuses primarily on changes in HHI due to acquisitions of failed banks, the choice of how to weight savings institutions deposits is largely immaterial.

${ }^{13}$ In calculating pro forma HHI values, I assume that acquirers purchase all of the deposits of failed banks, which I estimate to equal deposits held on the most recent June 30 before failure. However, acquirers sometimes purchase less than the total deposits of failed banks, and the deposits of failed banks on the date of failure can differ substantially from the amount held by the bank on the prior June 30 . Hence, the pro forma HHI values presented in this article are estimates of the effect of in-market acquisitions on market concentration that may overstate or understate the true effect.
}

State Bank, which held 95.4 percent of the county's bank deposits on June 30, 2008, was closed by the Texas Department of Banking on December 12, 2008. The FDIC sold all of the failed bank's assets and deposits to The Pecos County State Bank, which as the only other bank with offices in Terrell County, held 4.6 percent of the county's deposits on June 30, 2008. The acquisition of Sanderson State Bank by its sole in-market competitor increased the HHI value for Terrell County by 875 points, from 9125 to 10000 points.

Besides Terrell County, Texas, 12 other counties had market HHI values greater than 1800 on the June 30 before a bank failure and experienced an increase in HHI value of more than 200 points due to the acquisition of a failed bank by an inmarket competitor. Of course, the fact that these counties had highly concentrated banking markets that were made even more concentrated by the acquisition of failed banks does not imply that the FDIC ignored the competitive environment in soliciting bids for failed banks. Market competition is only one consideration in identifying potential bidders for failed banks, and the FDIC is required to pursue the least costly resolution of bank failures. ${ }^{14}$

Next, I examine the impact of acquisitions of failed banks in banking markets that had multiple in-market acquisitions within a 12-month period. Table 5 lists the markets with at least four such acquisitions. For example, between July 1, 2009, and June 30, 2010, there were 15 acquisitions of failed banks with offices in the Chicago MSA by banks that also had offices in Chicago on June 30, 2009. None of the failed banks had a large share of the Chicago banking market. Corus Bank, NA, had the largest share at only 2.5 percent. Among the acquiring banks, Harris Bank, NA, had the largest share of the Chicago market's bank deposits on June 30, 2009, at 8.6 percent. I estimate that

\footnotetext{
14 As shown in Table 4, some MSA banking markets have exceptionally large HHI values. However, most of these markets include the headquarters of a large national financial institution that assigns a large share of its customer deposits to the headquarters location. Because this skews measures of market concentration for those markets, regulators attempt to estimate the share of locally generated deposits in such organizations when evaluating the competitive implications of proposed mergers in affected markets. This article makes no such attempt.
} 
Table 3

Markets Where Acquisition of a Failed Bank Increased HHI by at Least 200 Points

\begin{tabular}{|c|c|c|c|c|c|}
\hline Market & $\begin{array}{c}\text { Failed bank } \\
\text { market share }(\%)\end{array}$ & $\begin{array}{c}\text { Acquirer } \\
\text { market share (\%) }\end{array}$ & $\begin{array}{l}\text { HHI before } \\
\text { acquisition* }\end{array}$ & $\begin{array}{c}\text { Pro forma } \\
\mathrm{HHI}^{+}\end{array}$ & $\begin{array}{c}\text { Difference } \\
\text { in } \mathrm{HHI}\end{array}$ \\
\hline \multicolumn{6}{|l|}{ County markets } \\
\hline Camden, GA & 39.2 & 14.3 & 2232 & 3352 & 1120 \\
\hline McDowell, WV & 31.6 & 17.7 & 3882 & 5001 & 1119 \\
\hline Kay, OK & 19.3 & 25.9 & 1622 & 2624 & 1002 \\
\hline Gilmer, GA & 10.2 & 49.0 & 3010 & 4007 & 997 \\
\hline Terrell, TX & 95.4 & 4.6 & 9125 & 10000 & 875 \\
\hline Crenshaw, AL & 11.6 & 35.6 & 2349 & 3178 & 829 \\
\hline Holt, NE & 12.1 & 32.1 & 2148 & 2927 & 779 \\
\hline Wharton, TX & 13.5 & 28.3 & 1638 & 2405 & 767 \\
\hline Elko, NV & 40.1 & 7.3 & 2329 & 2912 & 583 \\
\hline Montgomery, IA & 9.8 & 28.6 & 2397 & 2957 & 560 \\
\hline Blaine, ID & 43.5 & 5.2 & 2551 & 3001 & 450 \\
\hline Jo Daviess, IL & 7.0 & 28.5 & 2084 & 2483 & 399 \\
\hline Tift, GA & 16.7 & 10.8 & 2088 & 2448 & 360 \\
\hline Banks, GA & 11.7 & 14.9 & 3066 & 3416 & 350 \\
\hline Duplin, NC & 12.1 & 14.2 & 1990 & 2334 & 344 \\
\hline \multicolumn{6}{|l|}{ MSA markets } \\
\hline Bremerton, WA & 8.8 & 18.6 & 1214 & 1542 & 328 \\
\hline Houston, TX & 5.0 & 29.5 & 1161 & 1454 & 293 \\
\hline Anniston, AL & 13.6 & 10.4 & 1324 & 1606 & 282 \\
\hline Columbus, IN & 67.4 & 1.8 & 4822 & 5062 & 240 \\
\hline Beaumont, TX & 7.7 & 14.5 & 1051 & 1274 & 223 \\
\hline Mount Vernon, WA & 8.3 & 13.3 & 1026 & 1246 & 220 \\
\hline
\end{tabular}

NOTE: *HHI before acquisition is the value of the $\mathrm{HHI}$ in the market on June 30 of the year before the bank failure. ${ }^{+}$Pro forma $\mathrm{HHI}$ is a hypothetical value of $\mathrm{HHI}$ calculated under the assumption that the failed bank and acquirer had operated as a single institution on June 30 of the year before the failure.

the 15 acquisitions as a whole increased the HHI value for the Chicago market by just 24 points, from 563 to 587 points. Among the banking markets noted in Table 5, San Diego had the largest estimated increase in $\mathrm{HHI}$, at just 46 points. Hence, the evidence for markets with multiple in-market acquisitions of failed banks during a 12-month period indicates that the concentration of those markets was not substantially affected by the acquisitions.

Table 6 lists the markets with at least five acquisitions of failed banks by in-market com- petitors over the entire period from January 1, 2007, through December 31, 2010. To gauge the impact of all acquisitions during the period on market concentration, I compare the actual HHI values for June 30, 2006, with pro forma values constructed under the assumption that the failed banks and their acquirers had merged before that date. The difference between the "HHI After Acquisitions" and "Pro Forma HHI," therefore, provides an estimate of the impact of all in-market acquisitions of failed banks during 2007-10 on market concentration. For example, 22 banks with 


\section{Table 4}

Highly Concentrated Banking Markets (HHI > 1800) Where a Failed Bank Was Acquired by a Competitor

\begin{tabular}{|c|c|c|c|c|c|}
\hline Market & $\begin{array}{c}\text { Failed bank } \\
\text { market share }(\%)\end{array}$ & $\begin{array}{c}\text { Acquirer } \\
\text { market share }(\%)\end{array}$ & $\begin{array}{l}\text { HHI before } \\
\text { acquisition }^{+}\end{array}$ & $\begin{array}{c}\text { Pro forma } \\
\text { HHI }^{\ddagger}\end{array}$ & $\begin{array}{c}\text { Difference } \\
\text { in } \mathrm{HHI}\end{array}$ \\
\hline \multicolumn{6}{|l|}{ County markets } \\
\hline Terrell, TX & 95.4 & 4.6 & 9125 & 10000 & 875 \\
\hline McDowell, WV & 31.6 & 17.7 & 3882 & 5001 & 1119 \\
\hline Banks, GA & 11.7 & 14.9 & 3066 & 3416 & 350 \\
\hline Gilmer, GA & 10.2 & 49.0 & 3010 & 4007 & 997 \\
\hline Blaine, ID & 43.5 & 5.2 & 2551 & 3001 & 450 \\
\hline Chesterfield, SC & 3.1 & 20.1 & 2397 & 2522 & 125 \\
\hline Montgomery, IA & 9.8 & 28.6 & 2397 & 2957 & 560 \\
\hline Crenshaw, AL & 11.6 & 35.6 & 2349 & 3178 & 829 \\
\hline Elko, NV & 40.1 & 7.3 & 2329 & 2912 & 583 \\
\hline Camden, GA & 39.2 & 14.3 & 2232 & 3352 & 1120 \\
\hline Holt, NE & 12.1 & 32.1 & 2148 & 2927 & 779 \\
\hline Tift, GA & 16.7 & 10.8 & 2088 & 2448 & 360 \\
\hline Jo Daviess, IL & 7.0 & 28.5 & 2084 & 2483 & 399 \\
\hline Duplin, NC & 12.1 & 14.2 & 1990 & 2334 & 344 \\
\hline Martinsville, VA & 1.5 & 6.4 & 1958 & 1977 & 19 \\
\hline \multicolumn{6}{|l|}{ MSA markets } \\
\hline Reno, NV & $0.0^{*}$ & $0.0^{*}$ & 6803 & 6803 & 0 \\
\hline Bloomington, IL & 1.8 & 3.0 & 6528 & 6538 & 10 \\
\hline Ogden, UT & $0.0^{*}$ & $0.0^{*}$ & 5632 & 5633 & 1 \\
\hline Columbus, IN & 67.4 & 1.8 & 4822 & 5062 & 240 \\
\hline Columbus, IN & 5.5 & 1.8 & 4822 & 4841 & 19 \\
\hline Las Vegas, NV & $0.0^{*}$ & $0.0^{*}$ & 4658 & 4658 & 0 \\
\hline Las Vegas, NV & $0.0^{*}$ & $0.0^{*}$ & 4658 & 4658 & 0 \\
\hline San Antonio, TX & $0.0^{*}$ & $0.0^{*}$ & 3749 & 3750 & 1 \\
\hline San Antonio, TX & $0.0^{*}$ & 2.0 & 3749 & 3752 & 3 \\
\hline San Antonio, TX & $0.0^{*}$ & 2.2 & 3590 & 3592 & 2 \\
\hline Las Vegas, NV & 1.0 & 1.4 & 3129 & 3131 & 2 \\
\hline Trenton, NJ & $0.0^{*}$ & $0.0^{*}$ & 2978 & 2978 & 0 \\
\hline Jacksonville, FL & $0.0^{*}$ & $0.0^{*}$ & 2665 & 2665 & 0 \\
\hline Buffalo, NY & $0.0^{*}$ & 1.2 & 2514 & 2514 & 0 \\
\hline Minneapolis, MN & $0.0^{*}$ & $0.0^{*}$ & 2254 & 2254 & 0 \\
\hline Merced, CA & 38.9 & 2.0 & 2161 & 2317 & 156 \\
\hline Jacksonville, FL & $0.0^{*}$ & 1.1 & 2110 & 2110 & 0 \\
\hline Cincinnati, $\mathrm{OH}$ & $0.0^{*}$ & $0.0^{*}$ & 2028 & 2028 & 0 \\
\hline Racine, WI & 7.6 & $0.0^{*}$ & 1967 & 1974 & 7 \\
\hline Minneapolis, MN & $0.0^{*}$ & $0.0^{*}$ & 1873 & 1873 & 0 \\
\hline Minneapolis, MN & $0.0^{*}$ & $0.0^{*}$ & 1873 & 1874 & 1 \\
\hline Minneapolis, MN & $0.0^{*}$ & $0.0^{*}$ & 1873 & 1873 & 0 \\
\hline Minneapolis, MN & $0.0^{*}$ & $0.0^{*}$ & 1873 & 1873 & 0 \\
\hline Minneapolis, MN & $0.0^{*}$ & $0.0^{*}$ & 1873 & 1873 & 0 \\
\hline Dallas, TX & 1.8 & 2.9 & 1855 & 1866 & 11 \\
\hline Dallas, TX & $0.0^{*}$ & $0.0^{*}$ & 1855 & 1855 & 0 \\
\hline Cincinnati, $\mathrm{OH}$ & 1.0 & 2.7 & 1813 & 1818 & 5 \\
\hline
\end{tabular}

NOTE: *Less than 1 percent. ${ }^{+} \mathrm{HHI}$ before acquisition is the value of the $\mathrm{HHI}$ in the market on June 30 of the year before the bank failure. ${ }^{*}$ Pro forma $\mathrm{HHI}$ is a hypothetical value of $\mathrm{HHI}$ calculated under the assumption that the failed bank and acquirer had operated as a single institution on June 30 of the year before the failure. 
Table 5

Markets with Four or More Acquisitions of Failed Banks by Competitors in a Single Year

\begin{tabular}{|c|c|c|c|c|c|}
\hline Market* & Year $^{+}$ & $\begin{array}{l}\text { No. of } \\
\text { acquisitions }\end{array}$ & $\begin{array}{l}\text { HHI before } \\
\text { acquisitions }^{\ddagger}\end{array}$ & $\begin{array}{c}\text { Pro forma } \\
\text { HHIs }\end{array}$ & $\begin{array}{c}\text { Difference } \\
\text { in } \mathrm{HHI}\end{array}$ \\
\hline Chicago, IL & 2009-10 & 15 & 563 & 587 & 24 \\
\hline Los Angeles, CA & 2009-10 & 9 & 888 & 915 & 27 \\
\hline Atlanta, GA & 2008-09 & 7 & 1270 & 1279 & 9 \\
\hline Los Angeles, CA & 2008-09 & 7 & 774 & 781 & 7 \\
\hline Atlanta, GA & 2010 & 7 & 1248 & 1249 & 1 \\
\hline Seattle, WA & 2009-10 & 6 & 1097 & 1101 & 4 \\
\hline Miami, FL & $2009-10$ & 5 & 741 & 743 & 2 \\
\hline Minneapolis, MN & 2009-10 & 5 & 1873 & 1874 & 1 \\
\hline Riverside, CA & 2009-10 & 5 & 1011 & 1015 & 4 \\
\hline San Francisco, CA & 2009-10 & 5 & 1708 & 1714 & 6 \\
\hline Chicago, IL & 2008-09 & 4 & 537 & 554 & 17 \\
\hline Atlanta, GA & 2009-10 & 4 & 1181 & 1186 & 5 \\
\hline San Diego, CA & 2009-10 & 4 & 1029 & 1075 & 46 \\
\hline
\end{tabular}

NOTE: *All markets with four or more acquisitions are MSAs. ${ }^{+}$Years are the 12-month periods July 1, 2008-June 30, 2009, and July 1, 2009June 30, 2010, and the 6-month period July 1, 2010-December 31, 2010. ${ }^{*} \mathrm{HHI}$ before acquisitions is the value of the $\mathrm{HHI}$ in the market on June 30 of the year before the bank failures. \$Pro forma $\mathrm{HHI}$ is a hypothetical value of $\mathrm{HHI}$ calculated under the assumption that the failed banks and their acquirers had operated as combined institutions on June 30 of the year before the failures.

offices in Chicago that failed during 2007-10 were acquired by banks that also had offices in Chicago. If those failed banks and their acquirers had already merged by June 30, 2006, the estimated HHI for the Chicago market would have been 633 points ("Pro Forma HHI"). By contrast, the actual HHI for the Chicago market on June 30, 2006, was 600 points ("HHI Before Acquisitions"). Hence, I estimate that the acquisitions of the 22 failed banks by in-market competitors increased the HHI of the Chicago market by 33 points, or about 5.5 percent.

Among the markets listed in Table 6, Houston experienced the largest impact of such acquisitions on market concentration. I estimate the acquisitions of failed banks by in-market competitors increased the HHI of the Houston market by 323 points, or 27.8 percent. The next-largest impact was in the New York City market, where failed bank acquisitions increased the HHI by 112 points, or 9.9 percent. In both cases, the acquisition of Washington Mutual Bank by JPMorgan Chase Bank was the main reason for the increase in
HHI. The HHI values for both the Houston and New York City markets remained below 1800 after the acquisition, however, indicating that neither market was particularly concentrated.

Finally, I investigate the contribution of acquisitions of failed banks by in-market competitors to changes in the concentration of individual banking markets between 2006 and 2010. The median increase in HHI between June 2006 and June 2010 across all markets in which a failed bank was acquired by an in-market competitor was 90 points. I estimate that, absent acquisitions of failed banks by in-market competitors, the median increase in HHI would have been 10 points. ${ }^{15}$ However, such acquisitions account for a much smaller percentage of the increase in $\mathrm{HHI}$ among most MSA markets than among rural markets. Among the 89 MSAs with in-market acquisitions

${ }^{15}$ This is the median across all markets of the difference between HHI for June 2010 and a pro forma value for June 2006 constructed under the assumption that all failed banks and their acquirers had merged before June 30, 2006. 


\section{Table 6}

\section{Markets with at Least Five Acquisitions of Failed Banks by In-Market Competitors (2007-10)}

\begin{tabular}{|c|c|c|c|c|}
\hline Market* & $\begin{array}{c}\text { No. of } \\
\text { acquisitions }\end{array}$ & $\begin{array}{c}\text { HHI before } \\
\text { acquisitions }^{\dagger}\end{array}$ & Pro forma $\mathrm{HH}^{\ddagger}$ & Difference in $\mathrm{HHI}$ \\
\hline Chicago, IL & 22 & 600 & 633 & 33 \\
\hline Atlanta, GA & 18 & 1412 & 1421 & 9 \\
\hline Los Angeles, CA & 18 & 783 & 799 & 16 \\
\hline Seattle, WA & 10 & 1330 & 1335 & 5 \\
\hline Miami, FL & 8 & 833 & 836 & 3 \\
\hline Minneapolis, MN & 7 & 1566 & 1567 & 1 \\
\hline San Francisco, CA & 7 & 1372 & 1375 & 3 \\
\hline Riverside, CA & 7 & 939 & 945 & 6 \\
\hline Kansas City, MO & 6 & 408 & 409 & 1 \\
\hline Phoenix, AZ & 5 & 1510 & 1604 & 94 \\
\hline Detroit, MI & 5 & 1427 & 1430 & 3 \\
\hline Houston, TX & 5 & 1160 & 1483 & 323 \\
\hline New York, NY & 5 & 1131 & 1243 & 112 \\
\hline San Diego, CA & 5 & 1001 & 1049 & 48 \\
\hline
\end{tabular}

NOTE: *All markets with at least five acquisitions are MSAs. ${ }^{+} \mathrm{HHI}$ before acquisitions is the value of the $\mathrm{HHI}$ in the market on June 30 ,

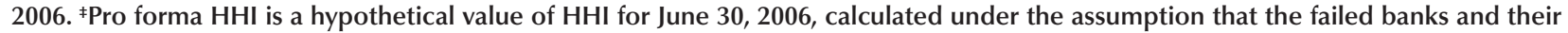
acquirers had operated as combined institutions on that date.

of failed banks, the median increase in HHI was 78 points. I estimate that absent such acquisitions, the median HHI would have increased by 50 points. By contrast, among the 27 rural markets where such acquisitions occurred, the median increase in HHI between 2006 and 2010 was 113 points. Absent those acquisitions, I estimate that the median change in $\mathrm{HHI}$ across those markets would have been a decline of 149 points. Thus, the effect of in-market acquisitions of failed banks on the concentration of rural banking markets was, on average, much greater than the effect of such acquisitions on the concentration of MSA markets.

Table 7 lists markets where the HHI value increased by at least 500 points between June 30, 2006, and June 30, 2010, and at least one failed bank was acquired by an in-market competitor. The table also shows pro forma HHI values on June 30, 2006, calculated under the assumption that banks that failed during 2007-10 had merged with their in-market acquirers before June 30,
2006 ("Pro Forma HHI 2006"). In four markets listed in Table 7, the in-market acquirers of failed banks did not have a presence on June 30, 2006, and, hence, the pro forma HHI values for 2006 are identical to the actual values. In a few ruralcounty markets, acquisitions of failed banks by in-market competitors can explain a high percentage of the actual increase in HHI value between 2006 and 2010. For example, for the Crenshaw County, Alabama, banking market, the actual HHI values in 2006 and 2010 were 2194 and 3382 points, respectively. The pro forma HHI value for Crenshaw County in 2006 is 3100 points. Thus, I estimate that the in-market acquisition contributed 906 points, or 76 percent, of the 1188point increase in HHI value for Crenshaw County between 2006 and 2010. Similarly, I estimate that an in-market acquisition contributed 1012 points, or 88 percent, of the 1148-point increase in HHI value for McDowell County, West Virginia, between 2006 and 2010. Other counties for which in-market acquisitions account for large shares 


\section{Table 7}

\section{Markets with an HHI Increase of at Least 500 Points (2006-10)}

\begin{tabular}{|c|c|c|c|c|c|}
\hline Market & HHI 2006* & HHI 2010' & $\begin{array}{l}\text { Increase in } \\
\mathrm{HHI}, 2006-10\end{array}$ & $\begin{array}{l}\text { Pro forma } \\
\text { HHI 2006 }\end{array}$ & $\begin{array}{c}\text { Increase in } \mathrm{HHI} \\
\text { due to acquisitions } \\
\text { of failed banks }\end{array}$ \\
\hline \multicolumn{6}{|l|}{ County markets } \\
\hline Terrell, TX & 5104 & 10000 & 4896 & 5104 & - \\
\hline Crenshaw, AL & 2194 & 3382 & 1188 & 3100 & 906 \\
\hline McDowell, WV & 3996 & 5144 & 1148 & 5008 & 1012 \\
\hline Jo Daviess, IL & 1821 & 2574 & 753 & 2276 & 455 \\
\hline Wharton, TX & 1735 & 2363 & 628 & 2520 & 785 \\
\hline Holt, NE & 2193 & 2803 & 610 & 2966 & 773 \\
\hline Montgomery, IA & 2415 & 2940 & 525 & 2415 & - \\
\hline Elko, NV & 2007 & 2522 & 515 & 2518 & 511 \\
\hline \multicolumn{6}{|l|}{ MSA markets } \\
\hline Reno, NV & 3462 & 7247 & 3785 & 3462 & - \\
\hline Las Vegas, NV & 4812 & 6209 & 1397 & 4815 & 3 \\
\hline San Antonio, TX & 2946 & 4066 & 1120 & 2953 & 7 \\
\hline San Francisco, CA & 1372 & 2332 & 960 & 1375 & 3 \\
\hline Pittsburgh, PA & 1520 & 2431 & 911 & 1521 & 1 \\
\hline Ogden, UT & 5762 & 6658 & 896 & 5763 & 1 \\
\hline Carson City, NV & 1060 & 1934 & 874 & 1060 & - \\
\hline Jacksonville, FL & 1929 & 2665 & 736 & 1930 & 1 \\
\hline Minneapolis, MN & 1566 & 2254 & 688 & 1567 & 1 \\
\hline Cincinnati, $\mathrm{OH}$ & 1442 & 2028 & 586 & 1455 & 13 \\
\hline
\end{tabular}

NOTE: *HHI 2006 is the value of the $\mathrm{HHI}$ on June 30, 2006. ${ }^{+} \mathrm{HHI} 2010$ is the value of the HHI on June 30, 2010. ${ }^{*}$ Pro forma $\mathrm{HHI} 2006$ is a hypothetical value of $\mathrm{HHI}$ for June 30,2006 , calculated under the assumption that the failed banks and their acquirers had operated as combined institutions on that date.

of the actual increases in HHI values include Jo Daviess County, Illinois; Wharton County, Texas; Holt County, Nebraska; and Elko County, Nevada. ${ }^{16}$

Aside from the few cases noted above, acquisitions of failed banks by in-market competitors can explain relatively little of the increase in $\mathrm{HHI}$ value between 2006 and 2010 for most markets, especially MSA markets. Among MSA markets where in-market acquirers of failed banks had offices on June 30, 2006, the largest difference

${ }^{16}$ Acquisitions of failed banks by in-market competitors can explain more than 100 percent of the actual increases in HHI values, as they do for Wharton County, Texas, and Holt County, Nebraska, because other factors, including changes in relative market shares of other banks, offset the impact of acquisitions of failed banks. between the actual and pro forma HHI values for 2006 is a mere 13 points for the Cincinnati, Ohio, market.

\section{CONCLUSION}

The structure of the U.S. banking industry has changed dramatically since the mid-1980s, when the number of U.S. banks reached a postWorld War II peak. Advances in informationprocessing technology and the removal of most legal barriers to branch banking have been the main drivers of a substantial consolidation of the banking industry (Berger, 2003). Much of the 
consolidation has taken the form of mergers of solvent banks. However, waves of failures, both in the late 1980s and early 1990s and again in the wake of the financial crisis and recession of 2007-09, also contributed to industry consolidation and, at least in some markets, substantial increases in concentration. ${ }^{17}$

Failures eliminated 318 U.S. banks during 2007-10, or about 4 percent of the total number of banks operating at the end of 2006. The assets and deposits of 171 of those failed banks were acquired by institutions that already had branches in markets served by the failed bank. Those acquisitions contributed to increased concentration of local banking markets. However, this article finds that except for a few rural banking markets, acqui-

${ }^{17}$ Data from the 1990s indicate that branching deregulation and industry consolidation did not generally increase the concentration of local urban banking markets, though it did increase concentration over larger geographic regions (Dick, 2006). sitions of failed banks by in-market competitors generally had only a small impact on market concentration. Most banks that failed during 2007-10 were small, and although many of those banks were acquired by much larger institutions, those acquisitions generally had little impact on market concentration. Acquisitions of larger banks that failed during 2007-10, such as the acquisition of Washington Mutual Bank by JPMorgan Chase Bank, also had only limited impact on the concentration in most of the banking markets involved. Among large MSAs, the Houston and New York City banking markets were most affected by the acquisition of Washington Mutual but both remained relatively unconcentrated after the acquisition. ${ }^{18}$

${ }^{18}$ This article does not investigate the impact on market concentration of acquisitions of certain distressed commercial banks, such as Countrywide Bank; Wachovia Bank, NA; and National City Bank, which were acquired by other banks without being declared failed and closed by regulators. Those acquisitions may have had significant impacts on concentration in some banking markets. Although not the subject of the present article, the data and methods used here could be applied to investigate the effects of these and other acquisitions on the concentration of individual banking markets. 


\section{Wheelock}

\section{REFERENCES}

Aubuchon, Craig P. and Wheelock, David C. "The Geographic Distribution and Characteristics of U.S. Bank Failures, 2007-2010: Do Bank Failures Still Reflect Local Economic Conditions?” Federal Reserve Bank of St. Louis Review, September/October 2010, 92(5), pp. 395-415; http://research.stlouisfed.org/publications/review/10/09/Aubuchon.pdf.

Baumol, William J.; Panzar, John C. and Willig, Robert D. Contestable Markets and the Theory of Industry Structure. Revised Edition. San Diego: Harcourt Brace Jovanovich, 1988.

Berger, Allen N. "The Economic Effects of Technological Progress: Evidence from the Banking Industry." Journal of Money, Credit, and Banking, April 2003, 35(2), pp. 141-76.

Berger, Allen N.; Demirgüç-Kunt, Asli; Levine, Ross and Haubrich, Joseph G. "Bank Concentration and Competition: An Evolution in the Making." Journal of Money, Credit, and Banking, June 2004, 36(3 Part 2), pp. 433-51.

Dick, Astrid A. "Nationwide Branching and Its Impact on Market Structure, Quality, and Bank Performance." Journal of Business, March 2006, 79(2), pp. 567-92.

Federal Deposit Insurance Corporation. Resolutions Handbook; www.fdic.gov/bank/historical/reshandbook/.

Federal Deposit Insurance Corporation. Summary of Deposits; www2.fdic.gov/sod/index.asp.

Gilbert, R. Alton. "Bank Market Structure and Competition: A Survey.” Journal of Money, Credit, and Banking, November 1984, 16(4 Part 2), pp. 617-45.

Gilbert, R. Alton and Zaretsky, Adam M. "Banking Antitrust: Are the Assumptions Still Valid?” Federal Reserve Bank of St. Louis Review, November/December 2003, 85(6), pp. 29-52; http://research.stlouisfed.org/publications/review/03/11/gilbert.pdf. 